\title{
PENGARUH MODEL PEMBELAJARAN CRH BERBANTUAN MEDIA AUDIO VISUAL TERHADAP HASIL BELAJAR IPS
}

\author{
G.H. Andika Pratama ${ }^{1}$, Ndara Tanggu Renda ${ }^{2}$, Ketut Pudjawan ${ }^{3}$ \\ 1,2,3 Jurusan Pendidikan Guru Sekolah Dasar \\ Universitas Pendidikan Ganesha \\ Singaraja, Indonesia \\ e-mail: gedehendra727@yahoo.com ${ }^{1}, \underline{\text { ndara.renda@yahoo.com² }}$, \\ ketutpudjawan@gmail.com ${ }^{3}$
}

\begin{abstract}
Abstrak
Penelitian ini bertujuan untuk mengetahui perbedaan hasil belajar IPS siswa kelas V SD di Gugus II Kecamatan Tejakula semester genap tahun pelajaran 2017/2018 antara kelompok siswa yang dibelajarkan menggunakan model pembelajaran Course Review Horay berbantuan media audio visual dan kelompok siswa yang dibelajarkan bukan menggunakan model pembelajaran Course Review Horay. Jenis penelitian ini adalah eksperimen semu dengan rancangan non equivalent post-test only control group design. Populasi penelitian ini adalah seluruh siswa kelas V SD di Gugus II Kecamatan Tejakula tahun pelajaran 2016/2017 sebanyak 162 orang. Sampel dalam penelitian ini adalah siswa kelas V SD Negeri 5 Les sebanyak 30 orang dan siswa kelas V SD Negeri 1 Les sebanyak 39 orang, yang ditentukan melalui teknik rondom sampling. Data hasil penelitian diperoleh melalui metode tes instrumen pilihan ganda yang dianalaisis menggunakan teknik analisis statistik deskriptif dan statistik infrensial (uji-t). Hasil penelitian menunjukkan bahwa terdapat pengaruh yang signifikan hasil belajar IPS antara kelompok siswa yang dibelajarkan menggunakan model pembelajaran Course Review Horay berbantuan media audio visual dan kelompok siswa yang dibelajarkan bukan menggunakan model Course Review Horay, dengan nilai t hitung = 2,384 lebih besar dari t tab $=1,980$. Artinya perbedaan dalam penerapan model pembelajaran dapat memengaruhi hasil belajar IPS siswa kelas V SD di Gugus II Kecamatan Tejakula semester genap tahun pelajaran 2017/2018. Rekomendasi untuk guru dalam meningkatkan hasil belajar IPS siswa kelas V di gugus II Kecamatan Tejakula adalah menggunakan model pembelajaran Course Review Horay berbantuan media audio visual.
\end{abstract}

Kata-kata kunci : model pembelajaran course review horay, media audio visual, hasil belajar IPS.

\begin{abstract}
This study aims to determine the difference of Fifth grade IPS learning outcomes of elementary school in Gugus II Tejakula Sub-district on even semester of 2017/2018 between group of students who are taught using Course Review Horay learning model with audio visual and group of students who are not taught using Course Review Horay learning model. This research is quasi experiment with non equivalent design post-test only control group design. The population of this study is all Fifth grade of elementary school students in Gugus II Tejakula sub-district academic year 2016/2017 in total of 162 students. The sample in this study is Fifth grade students of SD Negeri 5 Les in total 30 students and Fifth grade students of SD Negeri 1 Les counted 39 people, determined by random sampling technique. The result was obtained through multiple choice instrument test method which analyzed by using descriptive statistical and inferential statistical test (t-test). The result showed that there was a significant effect of IPS learning outcomes between groups of students who were taught using learning model of Course Reviews Horay helped by audio visual media and group of students who were not taught of using Course Review Horay model, with t-count $=2,384$ bigger than $\mathrm{t}$-tab $=$ 1,980 . This means that the difference application of learning model can affect the Fifth
\end{abstract}


grade's IPS learning outcomes in Gugus II Tejakula sub-district even semester of academic year 2017/2018. Recommendation for the teachers in improving the Fifth grade's IPS learning outcomes in Sub-district II Tejakula is to use learning model of Course Review Horay assisted by audio visual media.

Keywords: Course Review Horay Learning Model, Audio Visual Media, IPS Learning Result.

\section{Pendahuluan}

Negara Indonesia menuju ke arah sistem pendidikan yang lebih baik. Untuk menuju sistem pendidikan yang lebih baik tersebut, maka segala jenis bentuk pelaksanaan pendidikan di Indonesia harus memiliki dasar hukum yang kuat. Adapun dasar hukum pendidikan di Indonesia tersebut adalah UU RI No. 20 Tahun 2003 pasal 1 ayat 1 yang menyatakan, pendidikan adalah usaha sadar dan terencana untuk mewujudkan suasana belajar dan proses pembelajaran agar peserta didik secara aktif mengembangkan potensi dirinya untuk memiliki kekuatan spiritual keagamaan, pengendalian diri, kepribadian, kecerdasan, akhlak mulia, serta keterampilan yang diperlukan dirinya, masyarakat, bangsa dan negara.

Berdasarkan peraturan perundangan-undangan pendidikan tersebut, pemerintah menyadari betul bahwa pendidikan di Indonesia sangat penting sehingga terus berpacu untuk melakukan usaha sadar dalam peningkatan mutu dan kualitas pendidikan. Upaya-upaya yang telah dilakukan pemerintah untuk pemerataan pendidikan dan memajukan pendidikan di Indonesia adalah adanya program wajib belajar sembilan tahun, pendidikan gratis, program beasiswa untuk mereka yang tidak mampu, dan yang berprestasi. Selain itu juga adanya pertukaran pelajar, sistem kejar paket, home scooling, sekolah luar biasa, penelitian-penilitian yang dibiayai pemerintah, adanya sertifikasi guru, SM3T, dan dibuatkan fasilitas serta sarana prasarana penunjuang pembelajaran.

Begitu besarnya perhatian pemerintah terhadap pendidikan khususnya pada jenjang Sekolah Dasar (SD), SMP, dan SMA, maka sudah selayaknya sekolah terus berpacu mencetak lulusan terbaik untuk dapat menjadi pilar-pilar bangsa Indonesia yang kokoh dan cerdas. Sehingga negara Indonesia dapat terus bersaing dengan negara-negara di kawasan Asia Tenggara, Eropa dan Dunia. Yang pada kenyataanya pringkat pendidikan Indonesia di ASEAN masih berada di bawah Singapura, Brunai, Malaysia, dan Thailand (Welle, 2017). Negaranegara tersebut trus menunjukan taringnya dalam dunia pendidikan, sementara Indonesia masih tertatih dan berupaya melaksanakan perbaikan kurikulum baru yang telah dibuat, guna menemukan formula yang tepat untuk pendidikan Indonesia di era globalisasi dan sesuai dengan sosial budaya Indonesia.

Pembenahan sistem pendidikan yang baik tentunya berimbas pada sekolah serta kualitas lulusan yang dihasilkan. Pada era globalisasi diharapkan sekolah tidak hanya mencetak lulusan yang pintar namun juga memiliki sikap yang baik dan karakter yang baik. Dari sekian banyak mata pelajaran yang ada seperti Matematika, Bahasa Indonesia, IPA, IPS dan PKn. Mata pelajaran IPS mengemban tugas yang berat karena IPS mengembangakan dan mengangkat teori hubungan antar individu dengan individu, dan individu dengan kelompok dapat terjalin dengan baik.

Mata pelajaran IPS sangat penting dibelajarkan mulai sejak SD karena siswa pintar saja tidak cukup. Siswa juga harus pandai bergaul dengan teman, keluarga, masyarakat dan mulai mengetahui betapa tipisnya batas ruang dan waktu antar negara, dengan segala jenis budaya luar yang akan menggrogoti karakter-karakter siswa. Maka dari itu IPS menjadi mata pelajaran yang sangat penting untuk dibelajarkan dalam usaha mengenalkan budaya bangsa dan segala jenis interaksi yang terjadi dimasyarakat, sehingga siswa cerdas dalam memfilter segala sesuatu yang datang dari luar.

Menurut Siska (2016), Karakteristik Mata Pelajaran IPS SD adalah sebagi berikut, 
1. Bahan pelajarannya akan lebih banyak memperhatikan minat para siswa, masalahmasalah sosial, keterampilan berfikir serta pemeliharaan/pemanfaatan lingkungan alam.

2. Mencerminkan berbagai kegiatan dasar manusia.

3. Bahan pembelajaran bervariasi dari kewargaan negara, fungsional, humanistis.

4. Unsur-unsur sosiologi dan pengetahuan sosial lainnya melengkapi program pembelajaran IPS, demikian pula unsur-unsur sains, teknologi, matematika dan agama akan ikut memperkaya bahan pembelajaran.

Berdasarakan karakteristik mata pelajaran IPS tersebut di atas, maka hal itu menjadi sangat penting dilakukan agar siswa dapat menelaah serta mengatasi berbagai masalah yang sewaktu-waktu menimpanya dalam proses melakukan interaksi terhadap lingkungan sosialnya baik itu di lingkuangan masyarakat maupun lingkungan sekolah, dalam proses pendewasaan diri serta kematangan berfikir siswa. Di sekolah siswa akan bertemu berbagai pribadi dari latar belakang keluarga yang berbeda-beda, serta karakter siswa yang berbeda antara satu dan yang lain. Hal tersebut dapat menempa siswa dan membuat siswa banyak belajar dari berbagai kondisi yang dilalui. Maka dari itu mata pelajaran IPS penting dibelajarkan untuk memberikan pengertian dan juga arah yang baik dalam kehidupan sosial masyarakat.

Selain itu, disebutkan bahwa tujuan kurikulum IPS 2006 yang juga terdapat dalam Permendiknas Nomor 24 Tahun 2006 tentang Pelaksanaan Peraturan Menteri Pendidikan Nasional Nomor 22 Tahun 2006 dan Peraturan Menteri Pendidikan Nasional Nomor 23 Tahun 2006 dinyatakan bahwa,

Mata pelajaran IPS bertujuan agar peserta didik memiliki kemampuan sebagai berikut, (1) mengenal konsep-konsep yang berkaitan dengan kehidupan masyarakat dan lingkungannya; (2) memiliki kemampuan dasar untuk berpikir logis dan kritis, rasa ingin tahu, inkuiri, memecahkan masalah, dan keterampilan kehidupan sosial; (3) memiliki komitmen dan kesadaran terhadap nilai-nilai sosial dan kemanusiaan; (4) memiliki kemampuan berkomunikasi, bekerja sama dan berkompetisi dalam masyarakat majemuk, di tingkat lokal, nasional dan global.

Namun pada kenyataannya pelaksanaan pembelajaran IPS di lapangan, kurang sesuai dengan rancangan rasional tujuan yang sudah sangat sistematis dan baik. Dengan kata lain tujuan pembelajaran IPS yang ingin dicapai belum dapat terlaksana secara maksimal. Dari karaktersitik serta tujuan dalam perumusan mata pelajaran IPS maka sudah selayaknya tercipta generasi emas dan unggul, bukan semakin tergerus oleh arus globalisasi dan terjerumus ke dalam hal-hal yang kurang baik. Dewasa ini siswa mulai berbicara, berpakaian dan berprilaku tidak sopan kepada teman sepergaulan, orang tua dan guru, baik di lingkungan sekolah maupun di lingkungan masyarakat. Serta menurunnya kejujuran dalam berprilaku, yang dibarengi dengan merosotnya nilai-nilai dalam pelaksanaan pembelajaran IPS yang sangat penting untuk pembentukan kepribadian serta intelektual siswa.

Kesenjangan yang terjadi antara harapan dan kenyatan pada usaha membelajarakan mata pelajaran IPS yang belum maksimal juga terjadi di SD gugus II Kecamatan Tejakula, setelah melakukan penjajagan pada tanggal 10 Juli 2017. Berdasarkan hasil wawancara dengan beberapa guru kelas IV dan kelas $\mathrm{V}$ tentang kesulitan guru dalam membelajarkan IPS dan juga kesulitan siswa ketika belajar. Guru berasumsi metode ceramah efektif digunakan karena materi akan cepat selesai, dan bantuan beberapa contoh soal dapat memudahkan siswa mengerjakan soal-soal yang akan diberikan selanjutnya. Mengenai model, metode, serta teknik pembelajaran guru memang tidak begitu tahu, tetapi guru juga meyakini jika mampu menerapkan lebih banyak model, metode, serta teknik pembelajaran siswa akan lebih tertarik untuk belajar, bahkan meningkatkan pemahaman konsep dan hasil belajar siswa. Untuk saat ini guru hanya bisa menegur jika siswa didapati lain-lain ketika belajar, dan juga memberikan lebih banyak latihan soal-soal bahkan mengulangi menjelaskan pada siswa yang belum paham dan tidak bisa mengerjakan soal-soal latihan. Cara ini dianggap oleh guru masih bagus karena langsung masuk ke inti materi. 
Namun di sisi lain guru juga mengungkapkan keterbatasan dalam menerapkan model, metode pembelajaran dan kurang menghadirkan media pembelajaran, mengakibatkan kesulitan-kesulitan siswa ketika belajar IPS di kelas. Ketika belajar seringkali siswa enggan membaca bahan bacaan sehingga tidak mendapatkan informasi yang diinginkan. Siswa lebih suka cara yang lebih cepat ketika menyelesaikan tugas yang diberikan guru dengan cara melihat pekerjaan temannya yang belum tentu benar. Siswa juga cepat lupa dari apa yang telah dibaca. Pada saat belajar sangat terlihat kesenjangan antara siswa yang pintar dan siswa yang kurang pintar, siswa yang kurang pintar seringkali lebih asik berbicara dengan teman ketika guru menjelaskan materi. Dan yang paling menonjol adalah siswa cepat bosan dan cendrung kurang semangat setiap kali belajar.

Setelah melaksanakan wawancara, selanjutnya adalah melakukan observasi terhadap kegiatan pembelajaran IPS dibeberapa kelas V gugus II Kecamatan Tejakula. Pada kegiatan observasi pembelajaran IPS ditemukan masalah-masalah yang telah diungkapkan guru sebelumnya yaitu, guru kurang menguasai strategi dan model pembelajaran yang menyebabkan pembelajaran monoton. Hampir disetiap pembelajaran akan berlangsung aktifitas yang sama dan cenderung kaku karena kurangnya aktifitas fisik dari siswa belajar. Guru kurang memvariasikan media pembelajaran, padahal di sekolah sudah difasilitasi beberapa media pembelajaran yang mendukung. Minimnya penguatan saat belajar yang sebenarnya sangat penting dilakukan sebagi bentuk apresiasi guru kepada siswa karena telah belajar dengan baik. Adanya batasan tersalurnya informasi dari guru kesiswa ataupun sebaliknya karena siswa takut menyampaikan apa yang sebenarnya belum dimengerti. Selain itu guru sering mengajar dengan metode ceramah dari mulai belajar sampai akhir kegiatan pembelajaran, dan guru juga mengajar secara klasikal sehingga sangat terlihat kesulitan memberikan perhatian kepada semua siswa, yang menyebabkan pembelajaran menjadi kurang efektif.

Jadi masalah-masalah yang ditemukan pada saat wawancara maupun observasi diduga menyebabkan hasil belajar IPS siswa Kelas V SD yang berada di gugus II, Kecamatan Tejakula hasil belajar IPS rata-rata masih dibawah KKM.

Rata-rata nilai ujian akhir semster siswa kelas IV SD di gugus II Kecamatan Tejakula berada pada rentang 60,0 sampai dengan 62,0. Sedangkan rentang KKM berada pada rentang 63 sampai dengan 65, jadi dapat dicermati bahwa rata-rata hasil belajar siswa masih dibawah KKM. Dengan membandingkan rata-rata persentase yang diperoleh yaitu 60,7 dengan kriteria PAP, ternyata angka 60,7 berada pada kategori 40-64, sehingga disimpulkan rata-rata tersebut tergolong rendah. (Agung, 2016).

Dari 162 siswa kelas IV yang sekarang sudah berada di Kelas V SD gugus II Kecamatan Tejakula, hanya ada 47 siswa yang mampu tuntas dalam belajar IPS sedangkan 115 siswa nilai hasil belajar IPS masih di bawah KKM. Jika dipersentasikan siswa yang berhasil tuntas dalam belajar IPS kurang lebih $30 \%$ dan $70 \%$ masih belum tuntas. Beracuan dari data yang ada maka pembelajaran IPS kelas IV yang sekarang duduk di kelas V gugus II Kecamatan Tejakula perlu dilakukan pembaharuan ataupun inovasi yang dapat meningkatkan hasil belajar IPS.

Adapun pembaharuan ataupun inovasi dalam pembelajaran IPS yang dimaksud adalah guru diperkenalkan dengan model-model pembelajaran yang relevan dilakukan dalam pembelajaran IPS seperti model pembelajaran Course Review Horay. Model pembelajaran Course Revew Horay adalah pembelajaran yang menyenangkan dengan memadukan unsurunsur belajar dan juga permainan sederhana yang tidak menyebabkan siswa jenuh belajar karena siswa ikut berpartisipasi aktif dalam pembelajaran dengan teriak horay atau yel-yel jika siswa bersama kelompok berhasil menjawab benar soal-soal yang diberikan oleh guru. Menurut Kurniasih, Sani (2015:80) Model pembelajaran Course Review Horay merupakan "model pembelajaran yang dapat menciptakan suasana kelas menjadi meriah dan menyenangkan karena setiap siswa yang dapat menjawab benar maka siswa tersebut diwajibkan berteriak horay atau yel-yel lainnya yang disepakati”. Shoimin (2014:54) juga mengemukakan bahwa "Pembelajaran Course Review Horay merupakan salah satu 
pembelajaran kooperatif, yaitu kegiatan belajar mengajar dengan cara pengelompokan siswa ke dalam kelompok-kelompok kecil".

Jadi pembelajaran Course Review Horay adalah pembelajaran kooperatif. Sejalan dengan tujuan dari pembelajaran IPS yang mengharapkan siswa memiliki kemampuan berkomunikasi, bekerja sama dan berkompetisi dalam masyarakat majemuk. Karena di dalam pembelajaran yang kooperatif siswa dituntut untuk berinteraksi melalui kelompok-kelompok kecil yang dibentuk. Sehingga model pembelajaran Course Review Horay layak untuk dicobakan karena diyakini dapat meningkatkan keterlibatan siswa ketika belajar, baik itu secara fisik maupun fisikis siswa pada saat belajar. Selain itu kelompok yang dibentuk adalah kelompok kecil sehingga siswa dapat berlatih bekerjasama dengan anggota kelompok secara lebih kondusif, dan meminimalkan aktifitas anggota kelompok yang menyimpang.

Dalam penerapan model pembelajaran Course Review Horay, selain siswa berlatih bekerjasama, siswa juga berlatih mengembangkan kreatifitas dalam membuat yel-yel dan yang paling penting adalah semua siswa memiliki kesempatan yang sama berkontribusi dalam setiap aktifitas yang berlangsung di dalam kelas.

Shoimin, (2014:55) menyatakan kelebihan model pembelajaran course review horay adalah, (1) Menarik sehingga mendorong siswa terlibat di dalamnya, (2) Tidak monoton karena diselingi sedikit hiburan sehingga suasana tidak menegangkan. (3)Siswa lebih semangat belajar, (4) melatih kerjasama.

Jadi siswa tidak lagi diposisikan menjadi siswa yang pasif, duduk dengan disiplin tinggi mendengarkan ceramah guru yang cendrung membuat siswa bosan belajar. Karena pada dasarnya siswa kelas $\mathrm{V}$ adalah anak-anak yang lebih suka belajar dibarengi dengan permainan yang tetap berada pada kaidah-kaidah atau aktifitas belajar. Sehingga model pembelajaran Course Review Horay diyakini dapat dilaksanakan dan layak diujicobakan.

Selain itu model pembelajran Course Review Horay juga akan dibantu media audio visual. Kemajuan teknologi dalam bidang pendidikan juga sangat membantu khususnya dalam pemanfaatan media pembelajaran. Dalam penelitian ini media pembelajaran yang dipilih adalah media audio visual. Media audio visual adalah media yang dapat menampilkan gambar, video serta informasi-informasi yang dibutuhkan oleh siswa yang sulit ditemukan di buku, maupun lingkungan sekitar siswa sehingga dengan media audio visual siswa akan merasa lebih dekat dengan informasi yang dibutuhkan. Siswa juga bisa memperkaya informasi dan juga menggabungkan informasi-informasi yang didapat menjadi pengetahuan baru yang dimiliki. Berdasarkan uraian di atas maka, apabila seorang guru mampu menerapkan lebih banyak model pembelajaran pada mata pelajaran IPS dan juga memanfaatkan media pembelajaran akan sangat penting dalam rangka meningkatkan kualitas pembelajaran yang dilakasanakan. Oleh karena itu, dilakukan suatu penelitian yang berjudul Pengaruh Model Pembelajaran Course Review Horay Berbantuan Media Audio Visual Terhadap Hasil Belajar IPS Siswa Kelas V SD di Gugus II Kecamatan Tejakula Semester Genap Tahun Pelajaran 2017/2018.

\section{Metode}

Tempat pelaksanaan penelitian yang dilakuan adalah di SD Gugus II Kecamatan Tejakula, Kabupaten Buleleng yang meliputi 8 sekolah yaitu SD Negeri 1 Les, SD Negeri 2 Les, SD Negeri 4 Les, SD Negeri 5 Les, SD Negeri 1 Penuktukan, SD Negeri 2 Penuktukan, SD Negeri 3 Penuktukan, dan SD Negeri 4 Penuktukan pada rentang waktu penelitian yaitu semester II (Genap) tahun pelajaran 2017/2018.

Teknik pengambilan sampel yang digunakan dalam penelitian ini adalah Teknik random sampling dengan Teknik undian. Untuk mengetahui kemampuan siswa kelas $\mathrm{V}$ masing-masing dari Gugus II Kecamatan Tejakula setara atau tidak, maka terlebih dahulu dilakukan uji kesetaraan dengan menggunakan ANAVA satu jalur.

Berdasarkan Uji ANAVA satu jalur diketahui bahwa kelas V di Gugus II Kecamatan Tejakula merupakan kelas yang setara. Dengan hasil $F_{\text {hitung }}=0,19949$ dan $F_{\text {tabel }}=2,09$, ini 
berarti $\mathrm{F}_{\text {hitung }}<\mathrm{F}_{\text {tabel. }}$. Maka sekolah yang setara tersebut akan diundi kembali secara acak dari sampel yang sudah lolos uji kesetaraan, untuk menentukan sekolah yang akan dijadikan tempat untuk melaksanakan penelitian. Dari hasil undian diperoleh pasangan SD Negeri 1 Les dan SD Negeri 5 Les. Selanjutnya pada tahap akhir, sekolah yang telah terpilih kembali diundi secara acak untuk menentukan kelas eksperimen dan kelas kontrol. Hasil pengundian menyatakan SD Negeri 1 Les sebagai kelas kontrol, sementara SD Negeri 5 Les sebagai kelas eksperimen.

Penelitian ini untuk mengetahui pengaruh satu variabel bebas dan satu variable terikat. Variabel bebas adalah model pembelajaran Course Review Horay berbantuan media audio visual, sedangkan variabel terikat adalah hasil belajar IPS.

Hasil belajar IPS dapat berupa aspek kognitif, afektif, dan psikomotor yang diukur dengan menggunakan teknik tes maupun nontes. Fokus dalam penelitian adalah menilai siswa pada aspek kognitif saja. Untuk memperoleh data mengenai hasil belajar IPS siswa digunakan tes yang berupa pilihan ganda. Setiap butir soal apabila jawaban benar maka mendapat nilai 1 dan jika jawaban salah mendapat nilai 0 atau disebut tes berbentuk dikotomi. Hanya ada dua skor pada tes pilihan ganda, jadi tidak terdapat rentang skor antara skor yang menyatakan jawaban benar dan skor yang menyatakan jawaban salah.

Data yang diperoleh dari uji coba instrument dianalisis dengan menggunakan uji validitas butir tes, uji reliabilitas tes, indeks daya beda, dan indeks kesukaran butir. Pada penelitian ini, analisis dilakukan dengan menggunakan bantuan program Microsoft Office Excel 2007.

Data yang pertama didapat yaitu uji validitas. Ada 50 soal yang akan terlebih dahulu di uji judges dan hasil dianalisi dengan perhitungan Gregory. Berdasarkan perhitungan menurut Gregory, tes tersebut berada pada criteria sangat tinggi yaitu berada pada rentangan 0,80 1,00 yang artinya 50 butir soal dikatakan relevan. Maka dari itu 50 butir soal tersebut layak diujikancobakan kepada 60 orang siswa kelas V di SD Negeri 4 Les dan SD Negeri 1 Penuktukan. Kemudian hasilnya dianalisis dengan uji validitas butir dengan rumus korelasi point biserial. Hasil $r_{x y h i t u n g}$ dikonsultasikan dengan taraf signifikasi $5 \%$. Yang hasilnya ada 10 butir soal dinyatakan tidak valid dan 40 butri soal valid.

Analisi yang kedua adalah uji realibilitas. 40 butir soal yang sudah dinyatakan valid dilakukan uji reabilitas dengan menggunakan formula Kuder Richadson 20 (KR-20). Berdasarkan perhitungan dengan rumus tersebut, dari 40 soal diperoleh reliabilitas tes hasil belajar IPS $=0,98$ dengan derajat reliabilitas tes tergolong sangat tinggi.

Analisi ketiga adalah indeks daya beda. Berdasarkan perhitungan indeks daya beda diperoleh 15 butir soal kategori cukup baik, dan 25 butir kategori baik. Yang artinya 40 soal tersebut layak untuk dilakukan uji indeks kesukaran butir. Dari hasil perhitungan dengan rumus indeks kesukaran butir menunjukkan bahwa ada 14 butir soal dengan kriteria mudah, 26 buitr soal dengan krieteria sedang. Maka 40 soal tersebut akan digunakan post test hasil belajar IPS.

Metode analisis data yang digunakan adalah analisis statistik deskriptif dan statistik inferensial dengan menggunakan uji-t. Statistik deskriptif yang dicari adalah mean, median, modus dan standar deviasi. Uji-t digunakan untuk menguji hipotesis penelitian. Rumus uji-t yang digunakan adalah polled varians $\left(n_{1} \neq n_{2}\right.$ dan varians homogen dengan $\left.d b=n_{1}+n_{2}-2\right)$,

Uji prasyarat yang harus dilaksanakan terlebih dahulu sebelum melaksanakan uji prasyarat hipotesis adalah uji normalitas sebaran data dengan chi-kuadrat dan uji homogenitas varians dengan uji F.

\section{Hasil dan Pembahasan}

Untuk memperoleh gambaran tentang hasil belajar IPS, data dianalisis dengan analisis deskriptif agar dapat diketahui Mean (M), median (Md), Modus (Mo), dan standar deviasi. Rangkuman hasil analisis deskriptif disajikan pada table 1. 
Tabel 1. Rekapitulasi Hasil Perhitungan Hasil belajar IPS

\begin{tabular}{lll}
\hline \multicolumn{1}{c}{ Statistik Deskriptif } & \multicolumn{1}{c}{ Kelompok Eksperimen } & \multicolumn{1}{c}{ Kelompok Kontrol } \\
\hline Mean (M) & 31,18 & 28,51 \\
Median (Md) & 30,625 & 27,87 \\
Modus (Mo) & 31,75 & 28,5 \\
Varians & 25,82 & 37,098 \\
Standar Deviasi & 5,08 & 6,09 \\
Skor Minimum & 21 & 15 \\
Skor Maximum & 40 & 19 \\
Rentangan & 20 & 25 \\
\hline
\end{tabular}

Berdasarkan tabel 1, diketahui mean kelompok eksperimen lebih besar daripada mean kelompok kontrol. Kemudian data hasil belajar IPS dapat disajikan ke dalam bentuk kurva poligon seperti pada gambar 1.

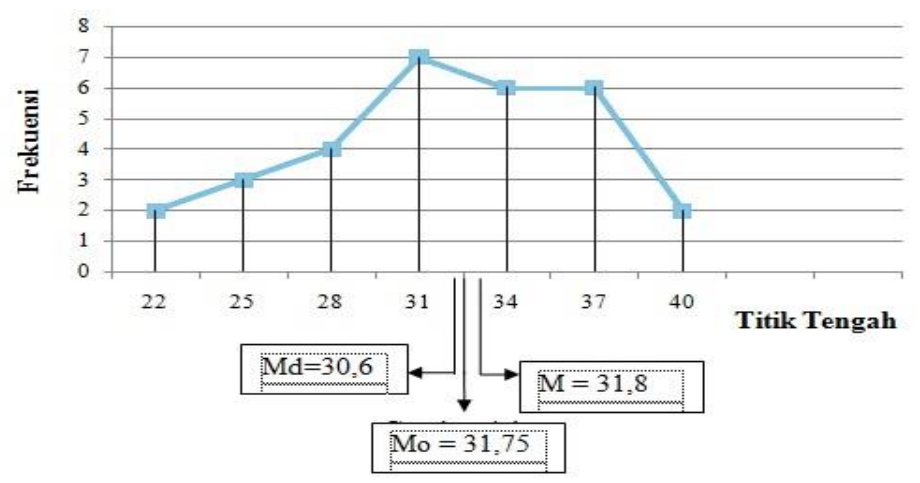

Gambar 1. Kurva Poligon Data Hasil Belajar IPS Kelompok Eksperimen

Mean (M), Median (Md), Modus (Mo) digambarkan dalam kurva poligon di atas merupakan kurva juling negatif $M>M o>M d(31,8>31,75>30,6)$. Hal ini menunjukkan bahwa sebagian besar skor siswa kelompok eksperimen yang dibelajarkan dengan model pembelajaran Course Review Horay berbantuan media audio visual cenderung tinggi. Jika nilai rata-rata dikonversikan ke dalam penilaian skala lima berada pada kategori sangat tinggi.

Distribusi frekuensi data hasil belajar IPS kelompok kontrol yang dibelajarkan dengan model pembelajaran bukan menggunakan model pembelajaran Course Review Horay disajikan pada gambar 2 .

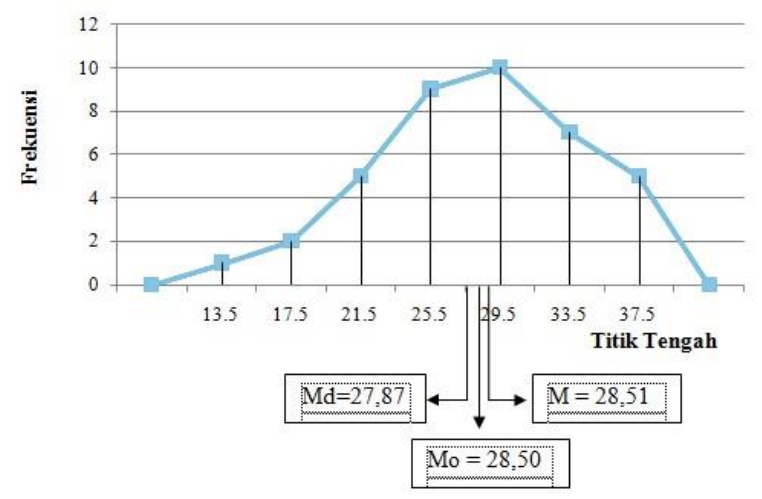

Gambar 2. Kurva Poligon Data Hasil Belajar IPS Kelompok Kontrol 
Mean (M), Median (Md), Modus (Mo) digambarkan dalam grafik polygon di atas merupakan juling negatif $(\mathrm{Md}<\mathrm{Mo}<\mathrm{M}) .(27,87<28,50<28,51)$. Hal ini menunjukkan bahwa sebagian besar skor siswa kelompok kontrol cenderung tinggi. Jika nilai rata-rata dikonversi ke dalam penilaian skala lima berada pada kategori tinggi.

Sebelum melakukan uji hipotesis terlebih dahulu dilakukan uji prasyarat yang meliputi uji normalitas dilakukan untuk membuktikan bahwa frekuensi data penelitian benar-benar berdistribusi normal. Hasil uji normalitas sebaran data didapatkan $\chi^{2}$ hit hasil post test kelompok eskperimen sebesar 2,05 dan $\chi_{\text {tab }}^{2}$ dengan derajat kebebasan $(\mathrm{db})=5$ pada taraf signifikansi $5 \%$ adalah 11,070 . Hal ini berarti $\chi^{2}$ hit hasil post-test kelompok eksperimen lebih kecil dari $\chi_{t a b}^{2}(2,053<11,070)$. Sehingga data hasil post-test kelompok eksperimen berdistribusi normal. Sedangkan $\chi^{2}{ }_{\text {hit }}$ hasil post-test kelompok kontrol adalah 1,129 dan $\chi_{\text {tab }}^{2}$ hasil post-test kelompok kontrol dengan derajat kebebasan $(\mathrm{db})=4$ pada taraf signifikansi $5 \%$ adalah 9,488. Hal ini berarti $\chi^{2}{ }_{h i t}$ hasil post-test kelompok kontrol lebih kecil dari $\chi_{\text {tab }}^{2}(1,129<9,488)$. Sehingga data hasil post-test kelompok kontrol berdistribusi normal.

Uji homogenitas varians dilakukan terhadap varians pasangan antar kelompok eksperimen dan kontrol. Uji yang digunakan adalah uji $F$ dengan kriteria data homogen jika $\mathrm{F}_{\text {hitung }}<\mathrm{F}_{\text {tabel }}$. Berdasarkan hasil perhitungan uji homogenitas didapatkan $\mathrm{F}_{\text {hitung }}$ sebesar 1,44 sedangkan $\mathrm{F}_{\text {tabel }}$ dengan $\mathrm{db}_{\text {pembilang }}=29$, db benyebut $=38$, pada taraf signifikansi $5 \%$ adalah 1,74 . Hal ini berarti $F_{\text {hitung }}$ lebih kecil dari $F_{\text {tabel }}(1,44<1,74)$ sehingga dapat dinyatakan bahwa varians data hasil post-test kelompok eksperimen dan kontrol adalah homogen.

Berdasarkan hasil analisis uji prasyarat hipotesis, diperoleh bahwa data hasil belajar Bahasa Indonesia siswa kelompok eksperimen dan kontrol adalah normal dan homogen, sehingga pengujian hipotesis penelitian dengan uji-t dapat dilakukan.

Uji hipotesis dilakukan dengan menggunakan statistic uji-t dengan rumus polled varians. Kriteria pengujian adalah $\mathrm{H}_{0}$ ditolak jika thitung $>$ tabel. Pengujian dilakukan pada taraf signifikansi $5 \%$ dengan derajat kebebasan $(\mathrm{dk})=\mathrm{n}_{1}+\mathrm{n}_{2}-2$. Hasil perhitungn uji-t dapat dilihat dalam Tabel 2.

Tabel 2. Hasil Uji-t

\begin{tabular}{llllllc}
\hline Kelompok & $\mathrm{N}$ & Db & Mean $(\bar{x})$ & $\mathrm{s}^{2}$ & $\mathrm{t}_{\text {hitung }}$ & $\mathrm{t}_{\text {tabel }}$ \\
\hline Eksperimen & 30 & 69 & 31,80 & 25,820 & 2,384 & 1,980 \\
Kontrol & 39 & & 28,51 & 37,098 & &
\end{tabular}

Berdasarkan tabel 4.7 dapat diketahui $\mathrm{t}_{\text {hitung }}=2,384$ dan $\mathrm{t}_{\text {tabel }}=1,980$ untuk $\mathrm{db}=69$ pada taraf signifikansi $5 \%$. Berdasarkan kriteria pengujian, karena $t_{\text {hitung }}>t_{\text {tabel }}$ maka $\mathrm{H}_{0}$ ditolak dan $\mathrm{H}_{1}$ diterima. Artinya terdapat perbedaan yang signifikan pada hasil belajar IPS antara kelompok siswa yang dibelajarkan dengan model pembelajaran Course Review Horay berbantuan media audio visual dan kelompok siswa yang dibelajarkan tidak menggunakan model pembelajaran Course Review Horay pada siswa kelas V SD di Gugus II Kecamatan Tejakula Semester Genap Tahun Pelajaran 2017/2018.

Pada penelitian ini, yang dibandingkan adalah model pembelajaran Course Review Horay berbantuan media audio visual dengan model pembelajaran bukan Course Review Horay terhadap hasil belajar IPS. Hasil uji hipotesis menunjukkan bahwa $\mathrm{HO}$ ditolak dan $\mathrm{H} 1$ diterima. Yang artinya terdapat perbedaan yang signifikan hasil belajar IPS antara siswa yang dibelajarkan menggunakan model pembelajaran Course Review Horay berbantuan media Audio Visual dan siswa yang dibelajarkan bukan dengan model pembelajaran Course Review 
Horay pada siswa kelas V SD gugus II Kecamatan Tejakula semester genap tahun ajaran 2017/2018.

Dalam penelitian ini didapati temuan-temuan yang menarik dalam pembelajaran kelas eksperimen yaitu hasil belajar IPS siswa dari setiap pertemuan yang mengalami peningkatan. Peningkatan hasil belajar siswa tersebut merupakan pengaruhi dari perubahan aktifitas belajar siswa. Pada kelas eksperimen siswa selalu ingin terlibat dalam pembelajaran terlihat dari hantusias siswa mencari informasi, menanya dan mengomunikasikan jawaban. Suasana kelas yang tidak tegang membuat siswa sangat menikmati langkah demi langkah pembelajaran, karena pembelajaran dibarengi dengan hiburan berupa teriakan horay atau yel-yel yang dibuat bersama dengan anggota kelompok. Sangat terlihat semangat siswa belajar yang menyebabkan informasi-informasi baru yang didapat lebih mudah diterima. Sehingga hasil tes hasil belajar IPS disetiap akhir pembelajaran meningkat.

$\mathrm{Hal}$ tersebut di atas sesuai dengan apa yang dikemukakan oleh para ahli model pembelajaran Course Review Horay bahwa model pembelajaran ini dapat meningkatkan minat siswa dalam belajar. Fatmawati, Ariesta, Susanti, Darmaji, Putra, (2015:30) menyatakan "Model Pembelajaran ini merupakan pembelajaran yang menarik motiasi siswa dengan penggunaan nomor dan yel-yel atau teriak horay dalam pembelajaran" yang di dalam pelaksanaan model pembelajaran Course Review Horay haruslah sesuai dengan sintak dan langkah-langkah sebagaimana yang terdapat pada kajian teori. Sehingga apa yang disampikan oleh Shoimin (2013) tentang kelebihan model pembelajran Course Review Horay yaitu "menarik sehingga mendorong siswa terlibat di dalamnya, tidak monoton karena di dalam pembelajaran ada selingan berupa hiburan ataupun permainan, siswa lebih semangat belajar, dan melatih kerja sama antar siswa", memang terjadi ketika model pembelajaran Course Review Horay diterapkan di kelas V SD pada kelompok eksperimen di gugus II Kecamatan Tejakula.

Model pembelajaran Course Review Horay selain memiliki kelebihan juga memiliki kekurangan Shoimin (2013) menyatakan kekurangan model pembelajaran ini adalah "adanya peluang untuk curang, siswa aktif dan pasif nilainya disamakan" untuk mengatasi hal tersebut ada beberapa cara yang telah dilakukan peneliti dan juga guru kelas pada kelompok eksperimen yaitu menggunakan stiker berbentuk bintang dan juga stiker senyum. Stiker tersebut sangat efektif meningkatkan keaktifan siswa dan juga mengetahui siswa yang tidak banyak berkontribusi pada kelompok pada saat belajar. Jadi semakin banyak stiker yang siswa peroleh maka semakin baik nilai yang akan siswa tersebut peroleh.

Aktifitas belajar yang monoton terjadi dikelompok kontrol. Aktifitas tersebut sudah tampak sejak awal observasi hingga sampai penelitian selesai. Siswa pada kelompok kontrol kurang hantusias untuk belajar (pasif), cepat bosan dan malas untuk membaca materi terlalu banyak. Suasana belajar tersebut yang pada awal penelitian memang diduga menyebabkan hasil belajar IPS siswa kelas $\mathrm{V}$ dibawah rata-rata. Ketika siswa masih belajar dengan cara yang sama dan guru juga masih tetap menggunakan cara mengajar yang sama yaitu mengajar dengan menerapkan metode ceramah dan penugasan. Menyebabkan hasil belajar siswa kelas $V$ pada kelompok kontrol tidak ada peningkatan hingga sampai penelitian selesai dilaksanakan.

Penerapan metode ceramah memang dirasa kurang mampu meningkatkan kognitif siswa selain itu juga aktifitas siswa menjadi kurang aktif menggali informasi guna kepentingkan pembejaran. Hal tersebut sesuai dengan pendapat dari Santoso (2013) tentang kekurangan metode ceramah yaitu "siswa menjadi pasif (tidak dilibatkan dalam pembelajaran), kurang kesempatan untuk pemecahan masalah, sulit mengevaluasi kemajuan belajar siswa, siswa sukar memusatkan perhatian dalam jangka waktu yang lama, hal-hal yang dapat diingat sedikit." Maka dari itu seperti apa yang telah dijelaskan pada teori, memang didapati sesuai dengan apa yang terjadi pada kelompok kontrol.

Dalam penerapan model pembelajaran Course Review Horay dibantukan dengan media audio visual pada tahapan penyajian materi ajar. Media audio visual yang dipilih pada penelitian ini adalah video. Video mampu menghadirkan informasi dalam bentuk visual dan audio yang disajikan secara bersamaan sehingga siswa yang belajar menggunakan visual atau 
audio dapat menyerap informasi dengan baik. Penggunaan media pembelajaran memang sangat membantu dalam proses pembelajaran seperti apa yang dikemukakan oleh Syamsidah (2016) media pembelajaran adalah "segala sesuatu yang dapat digunakan untuk menyalurkan pesan sehingga merangsang pikiran dan perasaan siswa untuk memperoleh pengetahuan pada saat proses belajar mengajar terjadi". Sesuai dengan teori tersebut maka memang benar siswa menjadi terangsang untuk dapat mendalami informasi dari setiap video yang ditampilkan pada tahap penyajian materi. Hal tersebut terlihat dari bagaiamana siswa memberikan reaksi atas video-video yang disajikan pada setiap kali pembelajaran dilaksanakan pada kelompok kontrol.

Reaksi-reaksi yang ditunjukan oleh siswa merupakan bentuk dari respon fikiran siswa atas apa yang dilihat. Reaksi yang sangat kentara adalah dalam bentuk pernyataan-pernyataan terbuka dengan teman sebangku atas video yang ditampilkan, meminta memutar kembali, dan yang paling jelas terlihat adalah ingatan siswa atas informasi yang terdapat dalam video yang ditonton bertahan lama. Hal ini memang sesuai dengan kebermanfaatan dari penggunaan media audio visual (video). Seperti apa yang dikemukakan oleh Munadi (2008) manfaat media audio visual adalah mengatasi keterbatasan jarak dan waktu, video dapat diulang bila kurang jelas, pesan yang disampaikan mudah diingat, mengembangkan pikiran dan pendapat siswa, membangun imajinasi siswa, kuat memengaruhi emosi siswa, baik dalam menjelaskan proses dan keterampilan, menumbuhkan minat dan motivasi belajar.

Perpaduan antara model pembelajaran Course Review Horay dan media audio visual (video) sangat baik untuk meningkatkan hasil belajar siswa kelas $\mathrm{V}$ pada kelompok eksperimen dibandingkan dengan pembelajaran yang bukan menggunakan model pembelajaran Course Review Horay (metode ceramah) di kelas V pada kelompok kontrol. Hal tersebut sudah terbukti dari hasil perbandingan tes hasil belajar siswa yang berupa tes kognitif siswa dalam bentuk soal-soal pilihan ganda. Model pembelajaran Course Review Horay selain mampun meningkatkan kognitif siswa pada kelompok eksperimen juga mampu merubah kebiasaan siswa belajar, dari yang pasif menjadi aktif, dari yang susah mengomunikasikan jawaban menjadi lebih terbuka dalam berkomunikasi di kelas, dan lebih meningkat dalam kerjasama untuk menyelesaikan suatu masalah yang ditemukan pada saat pembelajaran berlangsung. Hal-hal tersebut merupakan modal yang positif untuk dapat dilanjutkan dalam usaha meningkatkan hasil belajar IPS kelas V di gugus II Kecamatan Tejakula.

Hasil belajar menurut Rusman, (2015:67) berpendapat "Hasil belajar adalah sejumlah pengalaman yang diperoleh siswa yang mencakup ranah kognitif, afektif dan psikomotor. Maka berdasarkan teori tersebut pada penelitian ini melakukan penerapan model pembelajaran Course Review Horay berbantuan media audio visual dengan tujuan meningkatkan pengalaman-pengalaman belajar siswa sehingga apa yang menjadi fokus utama dalam penelitian ini dapat tercapai sesui dengan harapan. Benar saja kombinasi antara model dan media pembelajran yang dipilih membawa dampak yang positif dengan meningkatknya hasil belajar IPS siswa kelas V SD pada kelompok eksperimen. Seperti yang telah dijelaskan pada paragraf-paragraf awal, model pembelajaran Course Review Horay memiliki sintaks dan langkah-langkah pembelajaran yang sudah teruji sehingga ketika sintaks dan langkah-langakh tersebut dapat direalisasikan dengan baik oleh guru maka akan berpengaruh pada hasil akhir belajar siswa. Dapat diambil simpulan bahwa hasil belajar yang baik merupakan cerminan dari proses belajar yang telah dilalui siswa dengan baik pula.

Jadi hasil dari penelitian ini adalah berhasil meningkatkan kognitif pada dimensi berfikir C1 sampai dengan C4 siswa kelas V SD pada kelompok eksperimen di Gugus II Kecamatan Tejakula. Hasil penelitian ini sejalan dengan hasil dari beberapa penelitian tentang penerapan model pembelajaran Course Review Horay. Kariadnyani (2016), memaparkan bahwa terdapat perbedaan yang signifikan hasil belajar kognitif IPA antara kelompok siswa yang dibelajarkan dengan model pembelajaran kooperatif tipe Course Review Horay berbantuan multimedia kelas V SD tahun pelajaran 2015/2016 di Gugus II Dharma Tula Kecamatan Seririt. Sriwati (2014), menjelaskan bahwa dengan penerapan model pembelajaran Course Review Horay berbantuan media gambar untuk meningkatkan kemampuan berbahasa anak pada kelompok B semester II 
di TK Kumara Yasa Tegallinggah Tabanan, dapat berjalan secara intensif dan berkelanjutan. Laptta (2015), menyatakan bahwa penggunaan model pembelajaran Course Review Horay terdapat peningkatan hasil belajar pada kelas IV mata pelajaran IPA.

Berdasarkan temuan-temuan yang ada dalam penelitian ini, dapat dinyatakan bahwa siswa yang dibelajarkan dengan model pembelajaran Course Review Horay berbantuan media audio visual lebih unggul digunakan dibandingkan siswa yang dibelajarkan bukan menggunakan model pembelajaran Course Review Horay dalam hal pencapaian hasil belajar siswa dalam pembelajaran IPS.

\section{Simpulan dan Saran}

Berdasarkan hasil perhitungan data hasil belajar siswa, dapat disimpulkan bahwa siswa yang dibelajarkan dengan menggunakan model pembelajaran Course Review Horay berbantuan media audio visual memiliki hasil belajar yang lebih baik dengan peningkatan pembelajaran yang signifikan dibandingkan siswa yang dibelajarkan bukan dengan model pembelajaran Course Review Horay. Sehingga model pembelajaran Course Review Horay dapat dijadikan sebagai solusi untuk dapat meningkatkan hasil belajar IPS siswa di gugus II Kecamatan Tejakula untuk tahun selanjutnya.

Saran yang dapat disampaikan berdasarkan penelitian yang telah dilakukan adalah sebagai berikut. 1) Siswa di sekolah dasar agar dapat aktif dalam proses pembelajaran dan menggali banyak informasi yang tidak terbatas pada buku, ceramah guru di dalam kelas. Selain itu juga dapat menemukan solusi atas permasalahan yang dialami dalam proses interaksi dengan lingkungan. 2) Guru di sekolah dasar agar aktif berinovasi dalam merancang proses pembelajaran melalui penerapan model pembelajaran yang inovatif dan didukung media pembelajaran yang relevan guna meningkatkan ketertarikan siswa untuk belajar sehingga dapat meningkatkan hasil belajar siswa. 3) Sekolah yang mengalami permasalahan rendahnya hasil belajar IPS, disarankan untuk mengimplementasikan model pembelajaran yang lebih relevan dengan perkembangan zaman dan teknologi masa kini, misalnya model pembelajaran Course Review Horay berbantuan media audio visual (video) yang telah diteliti dapat mengingkatkan hasil belajar IPS siswa di sekolah. 4) Peneliti yang berminat untuk mengadakan penelitian lebih lanjut tentang model pembelajaran Course Review Horay berbantuan media audio visual (video) dalam mata pelajaran IPS maupun mata pelajaran lainnya agar memperhatikan kendala-kendala yang dialami dalam penelitian ini sebagai bahan pertimbangan untuk mengadakan perbaikan dan penyempurnaan penelitian yang hendak dilaksanakan.

\section{Daftar Pustaka}

Agung, A.A. 2016. Statistik Dasar untuk Pendidikan. Yogyakarta: Deepublish.

Kariadnyani, Kadek. Era. 2016. Pengaruh Model Course Review Horay Berbantuan Multimedia Terhadap Hasil Belajar IPA Siswa Kelas V SD. E-Journal PGSD Universitas Pendidikan Ganesha Jurusan PGSD, Vol. 4, No. 1.

Kurniasih, Sani. 2015. Ragam Pengembangan Model Pembelajaran Untuk Peningkatan Profesional Guru. Jakarta: Kata pena.

Lapatta, Jusman. 2015. Peningkatan Hasil Belajar Siswa Melalui Penggunaan Model Pembelajaran Course Review Horay Pada Mata Pelajaran IPA Kelas IV SD Inpres Sintuwu. Jurnal Kreatif Tadulako Online, Vol. 5, No.8. 
Permendiknas Nomor 24 Tahun 2006 tentang Pelaksanaan Peraturan Menteri Pendidikan Nasional Nomor 22 Tahun 2006 dan Peraturan Menteri Pendidikan Nasional Nomor 23 Tahun 2006.

Santoso, Budi. 2013. Skema dan mekanisme pelatihan Panduan Penyelanggaraan pelatihan. Jakarta: Terang.

Siska. 2016. Konsep Dasar IPS. Yogyakarta. Garudhawaca.

Shoimin, Aris. 2014. 68 Model Pembelajaran Inovatif dalam Kurikulum 2013. Yogyakarta: Pustaka Belajar.

Sriwati,Ni. Luh. Gede. 2014. Penerapan Model Pembelajaran Course Review Horay Bebantuan Media Gambar Untuk Meningkatkan Kemampuan Bahasa Anak. e-Journal PG-PAUD Universitas Pendidikan Ganesha Jurusan Pendidikan Guru Pendidikan Anak Usia Dini, Vol. 2, No. 1.

Welle,Deutsche. 2017. Rangking Pendidikan Negara-Negara Asean. http://www.dw.com/id/rangking-pendidikan-negara-negara-asean/g-37594464/ Desember 2017). 